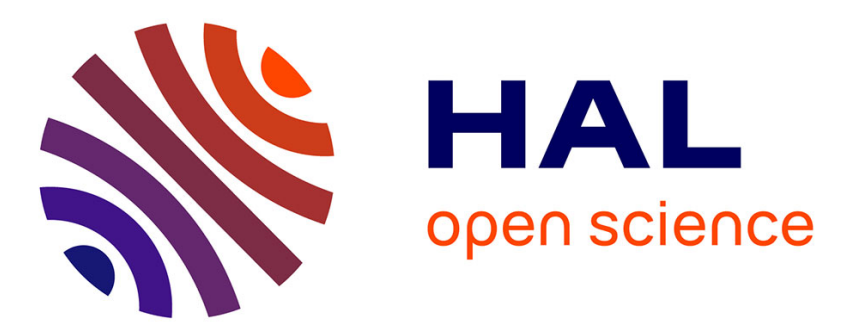

\title{
Proceedings of the 13th Workshop on Implementation, Compilation, Optimization of Object-Oriented Languages, Programs and Systems
}

Tim Felgentreff, Olivier Zendra

\section{- To cite this version:}

Tim Felgentreff, Olivier Zendra. Proceedings of the 13th Workshop on Implementation, Compilation, Optimization of Object-Oriented Languages, Programs and Systems. Tim Felgentreff; Olivier Zendra. 13th Workshop on Implementation, Compilation, Optimization of Object-Oriented Languages, Programs and Systems, ICOOOLPS 2018, Jul 2018, Amsterdam, Netherlands. ACM, 2018, 978-14503-5804-0. hal-02314731

\section{HAL Id: hal-02314731 \\ https://hal.inria.fr/hal-02314731}

Submitted on 13 Oct 2019

HAL is a multi-disciplinary open access archive for the deposit and dissemination of scientific research documents, whether they are published or not. The documents may come from teaching and research institutions in France or abroad, or from public or private research centers.
L'archive ouverte pluridisciplinaire HAL, est destinée au dépôt et à la diffusion de documents scientifiques de niveau recherche, publiés ou non, émanant des établissements d'enseignement et de recherche français ou étrangers, des laboratoires publics ou privés. 


\title{
Proceedings of the $13^{\text {th }}$ International Workshop on Implementation, Compilation, Optimization of Object-Oriented Languages, Programs and Systems
}

\author{
Co-located with the \\ European Conference on Object-Oriented Programming \\ (July 17, Amsterdam, Netherlands)
}

\section{Organizers}

Tim Felgentreff

Olivier Zendra
Oracle Labs Potsdam, Germany

INRIA / LORIA, France

With special thanks to all of our Program Committee members:

Nada Amin, Clément Béra, Shigeru Chiba, Benoit Daloze, Görel Hedin, Eric Jul, Stefan Marr, Eliot Miranda, Sarah Mount, and Tobias Pape.

The ICOOOLPS workshop series brings together researchers and practitioners working in the field of language implementation and optimization. The goal of the workshop is to discuss emerging problems and research directions as well as new solutions to classic performance challenges. 


\section{Table of Contents}

1. Assessing primitives performance on multi-stage execution

by Sophie Kaleba, Clément Béra, and Stéphane Ducasse

pages $1-10$

2. Maintaining Canonical Form After Edge Deletion

by Eric Fritz.

pages $11-22$

3. Extending SHAPES for SIMD Architectures - An approach to native support for Struct of Arrays in languages

by Alexandros Tasos, Juliana Franco, Tobias Wrigstad, Sophia Drossopoulou, and Susan Eisenbach pages $23-27$

4. GraalSqueak: A Fast Smalltalk Bytecode Interpreter Written in an AST Interpreter Framework

by Fabio Niephaus, Tim Felgentreff, and Robert Hirschfeld pages 28-33

5. Shared Memory Implementations of Protocol Programming Languages, Data-RaceFree

by Micha Hergarden and Sung-Shik Jongmans.

pages $34-37$ 


\section{About the review process}

All authors were asked to submit a paper for presentation at the workshop. Every paper was reviewed by at least three reviewers, who assessed the paper both for its quality to be presented at the workshop and inclusion in the post-workshop proceedings.

Number of papers initially submitted: 6

Number of papers accepted: 5 